\begin{tabular}{ccc}
\hline International Journal of Engineering \& Technology, $7(3.21)(2018) 293-300$ \\
SPC & Website: $w$ ww. sciencepubco.com/index.php/IJET \\
Research paper & Technology \\
\hline
\end{tabular}

\title{
Exploring Housing Governance in Malaysia
}

\author{
Chai Teng $\operatorname{Teoh}^{1 *}$, AbdulLateef Olanrewaju ${ }^{2}$, Seong Yeow $\operatorname{Tan}^{3}$, \\ ${ }^{1,2,3}$ Universiti Tunku Abdul Rahman, 31900, Kampar, Perak DR, Malaysia \\ *Corresponding author E-mail: chaitengteoh@gmail.com
}

\begin{abstract}
Malaysia, in this era of increasing globalisation and rapid pace of urbanisation coupled with socioeconomic inefficiency, is suffering from severe housing problems - most notably affordable housing crisis. Though several prescribed measures in terms of incentives, policies and schemes attempting to alleviate the affordable housing crisis has been implemented, so far the result has proven to be insignificant. With the housing industry today becoming ever more complex, fragmented and involved by an ever increasing number of heterogeneous stakeholders, thereby it is not applicable for the government to have a one-sided decision making power on housing and other related policies. As such, the 'governance' approach, which ably brings together both public and private housing stakeholders into a collective body of decision-making and actions, has been deemed as a prerequisite for dealing with the Malaysian housing dilemma. There has been much discussion about bringing governance into urban development, land delivery, construction projects or other related services to bring about positive effects. However, the housing industry in Malaysia, particularly in the affordable segment, has not adopted this approach to the same extent. In order to remedy this issue, this study aims to develop housing governance for the Malaysian affordable housing industry. This paper reports part of the study in achieving the mentioned aim by literature reviewing factors involved that negatively influence the Malaysian affordable housing delivery. It was identified that there are 65 indicators, classified into financial factors, policy and regulatory factors, administrative factors and knowledge factors that constrains the Malaysia affordable housing delivery.
\end{abstract}

Keywords: affordability; housing shortage; median income

\section{Introduction}

Homeownership for all citizens has always been a main goal for achieving proper living standards for most countries. Malaysia is no exception. The reasons are not difficult to fathom. Housing, first and foremost, is a basic and fundamental human need. Beyond that, it has vast economic, social and political spinoff contributions, whereas in long term, it can create stakes capable of fuelling the peace, stability and prosperity of a nation. But one of the biggest challenges in this country is the assault on homeownership, which can be linked to the affordability of housing. Provision of affordable housing is a global challenge (Woetzel et al., 2014), with Malaysia being no exception (Economic Planning Unit (EPU), 2010). Notably the United State (US), Australia, China, India and the Philippines have similar problems (Demographia, 2017; UN-Habitat, 2011). Malaysia has a population projected to reach 32.4 million by 2020 (DoS, 2016a) from 28.3 million in 2010 (Department of Statistic Malaysia (DoS), 2011). In tandem with Malaysia's rapid development, the proportion of urban population has reached $74.7 \%$ in 2015 from $71 \%$ in 2010 (Central Intelligent Agency (CIA), 2017; DoS, 2011). Between the years 2010-2015, the urban population grew at an annual average of $2.66 \%$, considerably higher than only $1.3 \%$ growth of total population (CIA, 2017). Its rate of urbanization is so rapid that cities are growing more rapidly in Malaysia than Japan (0.56\%), Australia (1.47\%), Singapore (2.02\%) and India (2.38\%) (CIA, 2017). This has led to rising housing demand, especially from the bottom and medium income groups (Ahmad and Hasmah, 2008). For instance, based on household formation at CAGR 3.07\% throughout the years between 2000 (4.8 million) and 2010 (6.35 million), the number of households in Malaysia is estimated to reach 8.59 million in 2020 (DoS, 2014). This represents an average annual household formation of about 224,000. Whilst, the average household size in 2010 was recorded to have rose to 4.2 people per household from 4.6 in 2000 (DoS, 2014), which is bigger than Japan (2.42), Australia (2.44), Hong Kong (2.92) and Singapore (3.5) (Nakono, 2017). Changes in the size of households can provide insight into the structure of households and trends in housing. By 2020, the Malaysia household size is forecasted to shrink further to 4 people per household (Khanzah Research Institute (KRI), 2015). Malaysia has seen a trend of deteriorating housing affordability and unmet housing needs that is contributing to a growing housing crisis. However, despite interventions in terms of policies, regulations and legislation being introduced by the Malaysian government, there is still a widening gap between supply and demand as well as the mismatch in product pricing and affordability in the domestic market, which becomes more evident in urban areas. Fragmented policies and housing strategies typically involving a range of stakeholders, along with separate rules and measures adopted at each level of government and regulatory bodies, has further compounded into the housing gap widening. Studies on housing issues and measures to ease the dilemma are well documented (KRI (2015), Cagamas (2013), Bank Negara Malaysia (BNM) (2016a)). Yet, the problem of existing literature in Malaysia is the focus on the issues of affordable housing crisis instead of the factors' driving aspect. More importantly, most suggestions and solutions fail to provide a basis for ongoing collaboration between internal and external housing stakeholders. Bearing this consideration in mind, it was argued that the prospect of delivering affordable housing hinge on housing players' coordination, cooperation, and collaboration (3Cs). 'Housing governance' is thus a suitable approach for Malaysia's property market, 
where the fragmented parties of various interest groups can be matched together via the 3Cs process and mechanism into a collective body of decision making and actions.

\section{Background}

Malaysia's gross domestic product (GDP) is largely supported by five key sectors: agriculture, mining and quarrying, manufacturing, construction and services. Among this sector, construction industry was accounted for $4.3 \%, 4.4 \%$ and $4.2 \%$ to the national (GDP) in 2014, 2015 and 2016 respectively (Construction Industry Development Board (CIDB), 2016). Despite being the smallest contributor as compared to other sectors, the construction industry remain as a key role in the aggregate economy of the country with emphasis on its strong correlation to the Malaysia economic growth (Khan et al., 2014). Residential, non-residential, social amenities and infrastructure are all construction sub-sectors (CIDB, 2016). For instance, the Malaysian property market is grouped into five main assets comprising residential, commercial, industrial, agricultural and development land. Of that, the residential sub-sector takes the lead in dominating the market. Statistics show that Malaysia in 2016 has a total of 4,945,140 residential units in the market (National Property Information Centre (NAPIC), 2017a), from a total of 4,435,736 in 2010 (NAPIC, 2016a). This can be interpreted as an annual home production rate of approximately 84,900 units. Taking into account the requirement of one household per residential unit, average home production rate is far from the household formation rate $(224,000$ per year). This serves as an unbalancing influence on the housing market. With continuous increment in Malaysia's population and the trend of shrinking household size, CIDB (2017) analysed that as of 2017, the country needs to have an additional 1.2 million of housing units to meet the housing demand, while BNM suggests that the shortage of affordable housing would exceed 1 million units by 2020 (Cheah and Stefanie, 2017). Indeed, the country has exceeded 2 million units of housing shortage since 2011 which is estimated to escalate further to more than 3 million by $2020^{\mathrm{p}}$ (Table 1 ). Based on existing average home production rate at 84,900 annually, within 35 years housing shortage would reach 3.02 millionunits.

Table 1: Malaysia Housing Supply Gap

\begin{tabular}{|l|l|l|l|l|l|l|l|l|}
\hline & $\begin{array}{l}\mathbf{2 0 1} \\
\mathbf{0}\end{array}$ & $\begin{array}{l}\mathbf{2 0 1} \\
\mathbf{1}\end{array}$ & $\begin{array}{l}\mathbf{2 0 1} \\
\mathbf{2}\end{array}$ & $\begin{array}{l}\mathbf{2 0 1} \\
\mathbf{3}\end{array}$ & $\begin{array}{l}\mathbf{2 0 1} \\
\mathbf{4}\end{array}$ & $\begin{array}{l}\mathbf{2 0 1} \\
\mathbf{5}\end{array}$ & $\begin{array}{l}\mathbf{2 0 1} \\
\mathbf{6}\end{array}$ & $\begin{array}{l}\mathbf{2 0 2 0} \\
\mathbf{p}\end{array}$ \\
\hline $\begin{array}{l}\text { Housing } \\
\text { units } \\
\text { ('mil) }\end{array}$ & 4.43 & 4.54 & 4.62 & 4.72 & 4.84 & 4.92 & 4.94 & $5.28^{1}$ \\
\hline $\begin{array}{l}\text { No. of } \\
\text { House- } \\
\text { hold } \\
\text { ('mil) }\end{array}$ & 6.35 & 6.56 & 6.73 & 6.97 & 7.13 & 7.29 & 7.46 & $8.3^{2}$ \\
\hline $\begin{array}{l}\text { Housing } \\
\text { supply } \\
\text { gap ('mil) }\end{array}$ & - & - & - & - & - & - & - & -3.02 \\
\hline
\end{tabular}

(Constructed based on NAPIC (2016a), NAPIC (2017a), DoS (2014), Euromonitor (2017), Author calculations)

Additionally, Malaysia House Price Index (MHPI) saw consistent annual rate increase, but has been on a moderate trend since 2014 associated with various cooling measures to contain spiralling prices (Figure 1) (NAPIC, 2017b). However, Malaysia is still experiencing high increment index changes compared to Singapore $(-2.62 \%)$, Australia $(2.12 \%)$ and Japan $(2.15 \%)$ in the 12 months leading up to Q3 2016 (IMF, 2017). Growth in aggregate house prices is expected to remain stabilised, as house buyers and developers continued to adjust to macro-prudential and fiscal measures aimed at curbing excessive speculation and risk-taking (BNM, 2016b). In 2016, the Government has mandated that all new houses priced up to RM300,000 to be limited to first-time homebuyers (NAPIC, 2016b), which they considered is affordable. This price provides a reference point for developers in pricing the newer launches, thereby facilitating a rebalancing of housing supply towards more affordable segment (BNM, 2017). But the pace of adjustment continues to be slow. In 2016, only $36.51 \%$ from total 52,713 newly launched residential units is in the price categories of RM300,000 and below (percentage interpretation based on NAPIC, 2017c). Indeed, the newly launched residential units decreased from 86,997 in 2014 to 70,273 units in 2015.

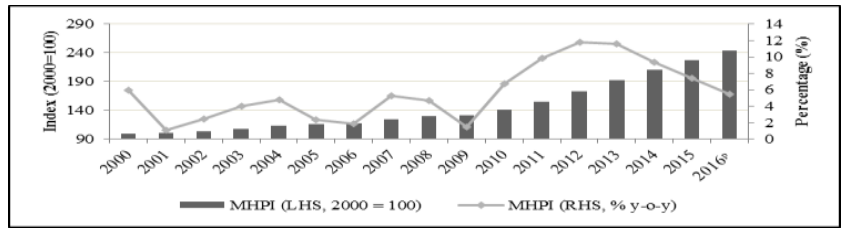

Fig. 1: Malaysia House Price Index (MHPI) (constructed based on NAPIC, 2017b)

Declining new housing launches reflects the cautious sentiment among housing developers and weak momentum amid the challenging environment of housing market (EPU, 2016; CIDB, 2017). This in turn increases the risks associated with an unsustainable supply of housing concentrated in specific segments, for example, the higher-price categories. Though there are 14,193 of unsold units as of Q3 2016, yet the developers opted to convert them into commercial accommodations (such as hotel suites) in efforts to clear the housing stock rather than lowering the price (BNM, 2017). Considering that the private supply in Malaysia amounted to the largest share of residential buildings (see Table 2), private developers' in initiating new launches will spill over the property market. With over $90 \%$ of the industry relying on the private sector for providing housing services, this highly suggests that the role of state has shifted from control to influence and from direct provision to steering plus enabling.

The NAPIC statistics show that the residential property transaction contributed for more than average $63 \%$ in terms of volume and $47 \%$ in terms of value towards total market and value transaction in the last five years (see Table 3). While this trend will most probably continue, the government effort in realizing the National Key Result Areas (NKRA), which is "raising the living standard of low-income households", and National Housing Policy on increasing homeownerships needs to be taken into account. However, the homeownership rate shows a gradual downward trend from $63.2 \%$ in 2000 to $55.8 \%$ in 2010 (DoS, 2014), and is projected to be less than $50 \%$ in 2020 (Olanrewaju et al., 2016). This indicates a growing housing affordability crisis, where fewer people are buying homes due to fewer people being able to afford it. As of Q3 2016, only 65\% of housing property is transacted at RM300,000 and below (percentage interpretation based on NAPIC, 2017d), while most average transacted house were priced between RM435,000 and RM1.1million (BNM, 2017)

The discrepancy between household income and house pricing was also exacerbated since 2012 by the slower increase in household incomes $(12.4 \%)$ relative to house prices (17.6\%) (BNM, 2017; Cheah and Stefanie, 2017). At the national level in 2016, median house prices is estimated as RM296,023 (2014: RM242,000; CAGR 10.6\% (KRI, 2015)) and will exceed the median annual household income estimated at RM68,640 (2014: RM4,585; CAGR 11.7\% (DoS, 2015a)) by 4.31 times compared to the Demographia International standard for housing affordability at 3 times. This indicates that the Malaysian housing market as a whole is in a "seriously unaffordable" condition. For instance, cumulatively the rate is higher compared to in the US (3.6), Canada (3.9) and Japan (4.1) (Demographia, 2017). Benchmarked against the median multiple (MM) approach, Malaysian in 2016 can only afford to buy a house estimated at around RM 205,900 
Table 2: Value and Share of Construction Work Done for Residential Buildings by Project Owner 2010-Q3/2016

\begin{tabular}{|c|c|c|c|c|c|c|c|c|}
\hline \multirow{2}{*}{$\begin{array}{c}\text { Quarter } \\
\text { Year }\end{array}$} & \multicolumn{2}{|c|}{ Private } & \multicolumn{2}{|c|}{ Government } & \multicolumn{2}{|c|}{ Public Corporation } & \multicolumn{2}{|c|}{ Total } \\
\hline & ( RM'000) & $\%$ & (RM'000) & $\%$ & (RM'000) & $\%$ & (RM'000) & $\%$ \\
\hline Q1- Q3/2016 & $25,521,465$ & 90.52 & $1,056,023$ & 3.75 & $1,615,070$ & 5.73 & $28,192,558$ & 100 \\
\hline 2015 & $31,135,954$ & 91.99 & $1,281,675$ & 3.79 & $1,428,608$ & 4.22 & $33,846,237$ & 100 \\
\hline 2014 & $28,295,662$ & 92.72 & 965,320 & 3.16 & $1,255,231$ & 4.11 & $30,516,213$ & 100 \\
\hline 2013 & $23,581,037$ & 94.46 & 864,413 & 3.46 & 520,776 & 2.08 & $24,963,226$ & 100 \\
\hline 2012 & $19,624,697$ & 94.04 & $1,123,984$ & 5.39 & 119,187 & 0.57 & $20,867,868$ & 100 \\
\hline
\end{tabular}

(Constructed based on MHLG, 2016, Author calculations)

Table 3: Volumes and Value of Residential Traensaction, 2010-2015

\begin{tabular}{|c|c|c|c|c|c|c|}
\hline \multirow[b]{2}{*}{ Year } & \multicolumn{2}{|c|}{ Residential } & \multicolumn{2}{|r|}{ Total } & \multicolumn{2}{|c|}{ Percentage $(\%)$} \\
\hline & Volume & Value (RM' mil) & Volume & Value (RM' mil) & Volume & Value (RM' mil) \\
\hline 2010 & 226,874 & $50,654.16$ & 376,607 & $107,439.55$ & 60.24 & 47.14 \\
\hline 2011 & 269,789 & $61,831.56$ & 430,403 & $137,828.04$ & 62.68 & 44.86 \\
\hline 2013 & 246,225 & $72,060.41$ & 381,130 & $152,372.12$ & 64.60 & 47.29 \\
\hline 2014 & 247,251 & $82,059.59$ & 384,060 & $162,974.38$ & 64.37 & 50.35 \\
\hline 2015 & 235,967 & $73,469.89$ & 362,105 & $149,897.95$ & 65.16 & 49.01 \\
\hline
\end{tabular}

(Constructed based on NAPIC, 2016c)

(Without any other debt obligations or savings). The situation even more dire as only $54.9 \%$ of household in 2014 earned less than RM5,000 monthly (percentage interpretation based on DoS, 2015b). Notably, prevailing median house prices is beyond the reach of most Malaysians, particularly for those who are bottom 40 (B40) and middle 40 (M40) households with an estimated median income of RM3,186 (2014: RM2,629 (EPU, 2015); CAGR $10.1 \%$ ) and RM6,624 (2014: RM5,465 (EPU, 2015); CAGR $10.1 \%$ ) in 2016. Since household income is not linked to an index, the cost of homeownership can quickly exceed the households' capacity to pay (Milken Institute, 2014). Total household debt, in fact, stood at RM1.086 trillion (88.4\%) to GDP by the end of 2016 (BNM, 2017), where $46 \%$ of these debts are tied to housing loans. In 2016, the national household expenditure is estimated at RM3,584 (2014: RM2,946 (KRI,2016); CAGR 10.3\%). Of that, $23.8 \%$ is composed of rental and utilities' bill. This figure reaches $38.9 \%$ if further accounting for furnishings, household equipment and routine household maintenance and transport, and is slightly higher than the figure in Japan (2016: 37\% ${ }^{4}$ ) (JMA, 2017). As per US Department of Housing and Urban development where financing of homeownerships shall exceed no more than 30 percent of monthly household gross income (including utilities), this suggests that homeownership cost in Malaysia is higher than that of an affordable standard, indicating that Malaysians are experiencing housing cost overburden. Worst still, an average of $50 \%$ out of total loan applications between 2010-2016 has been rejected, with 2016 having the lowest approval rate of $41.2 \%$, as compared to the highest 53.3\% in 2014 (Figure 2) (REHDA, 2016). The reasons behind this arise from the tightened lending policies and stricter financing guidelines, particularly for first-time home buyers in order to mitigate household risk in relation to household debts and improve the financial buffers of borrowers (BNM, 2017).

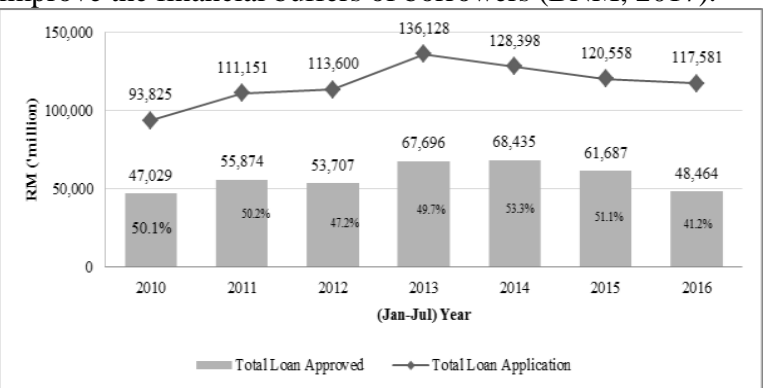

Fig. 2: Housing Loan Applied and Approved (constructed based on REHDA, 2016)

To increase the supply, the government has intervened in a number of ways: introducing National Housing Policy (NHP) in 2011, establishing National Housing Council (NHC) in 2014, imple- menting various public affordable housing schemes and programmes such as 1Malaysia People's Housing programme (PR1MA), 1Malaysia Civil Servants Housing (PPA1M), People's Housing Programme (PPR), Housing Aid Programme (PBR) and 1Malaysia People-Friendly Houses (RMR1M) as well as resolving abandoned housing projects. Despite all the hype, the government has yet to be proactive in supporting its policies. For example, the federal government development expenditure (DE) on housing subsector experienced substantial reduction from an annual fiscal allocation of RM2,008 million and RM2,476 million in 2015 and 2016 to only RM870 million or $1.9 \%$ of the total DE (EPU, 2017b). Even if this allocation is fully utilised, only about either 5,700 units of link house or 2,951 units of multi-storey house could be provided (considering RM152,500 and RM294,800 the average cost of construction per unit for link house and multistorey (CIDB, 2017)), which is far from the target for public housing during $11^{\text {th }}$ Plan by an average annual production at 130,600 units (total 653,000 public housing units).

\section{Outline of Study}

Literature review is carried out to identify the factors influencing Malaysian affordable housing supply and categorising them into homebuyer (Table 4), private sector (Table 5) and public sector (Table 6) perspectives.

\section{Finding and Interpretation}

Governance is the process by which parties collectively solve their problems and meet the society's needs (cited in Murphy pat, 2000) that explicitly includes a range of non-government actors (Beer, 2012). Applying this definition to the affordable housing aspect, 'governance', thus, is the process in which the housing stakeholders, both government and non-government, are collectively solving the housing provision problem and meeting the home-buyer needs and objective - to own a house. The author called this as 'housing governance'. To solve the problems, it is essential to ask what factors has limited the affordable housing demand and what factors has undermined the developer supply's ability to produce enough affordable housing and priced reasonably for the mass market. Based on 39 existing literature in Malaysia, a list of 65 factors which account for the current Malaysia affordable housing crisis (after deducting four repetitive (Rep.) factors: high land prices/cost, high prices of infrastructure provisions, scarcity of land and high construction cost) related to the public sector, private sector and home-buyers was reviewed and identified. Detailed observation on these factors can be grouped into four clusters; financial factors, policies and regulatory factors, administrative factors and knowledge factors (Figure 4). 
Table 4: Homebuyer Impediment Factors to Affordable Housing Supply

\begin{tabular}{|c|c|c|c|c|c|c|c|c|c|c|c|c|c|c|c|}
\hline$\stackrel{\Xi}{E}$ & 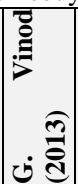 & 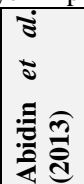 & 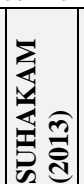 & 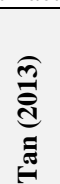 & 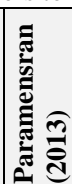 & 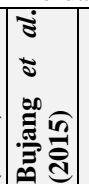 & 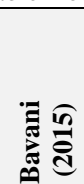 & 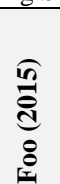 & 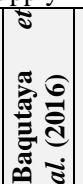 & 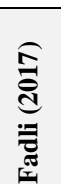 & 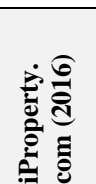 & 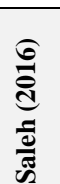 & 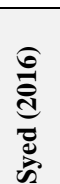 & 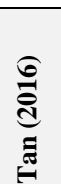 & $\frac{\pi}{0}$ \\
\hline $\begin{array}{l}\text { 1. Lack of awareness \& knowledge on housing } \\
\text { right and related policy }\end{array}$ & & & $\mathrm{x}$ & & & & & & & & & & $\mathrm{x}$ & & 2 \\
\hline 2. $\quad$ Difficulty in Access to home financing & & $\mathrm{x}$ & $\mathrm{x}$ & $\mathrm{x}$ & & $\mathrm{x}$ & & $\mathrm{x}$ & $\mathrm{x}$ & & $\mathrm{x}$ & & & $\mathrm{x}$ & 8 \\
\hline $\begin{array}{l}\text { 3. Housing are offered onsite or not suitable } \\
\text { area }\end{array}$ & & & & & & $\mathrm{x}$ & & & & & $\mathrm{x}$ & & & & 2 \\
\hline 4. Less housing choice available & & & & & & & & & $\mathrm{x}$ & & & & & & 1 \\
\hline 5. High loan interest rate & & $\mathrm{x}$ & & & & & & & & & & & & & 1 \\
\hline $\begin{array}{ll}\text { 6. } & \text { Less publicized information on affordable } \\
\text { housing \& application process }\end{array}$ & & $\mathrm{x}$ & & & & & & & & & & & & & 1 \\
\hline $\begin{array}{l}\text { 7. } \\
\text { Haym housing deposit / Insufficient down } \\
\text { payment }\end{array}$ & & & & & & $\mathrm{x}$ & & & & & $\mathrm{x}$ & & & & 2 \\
\hline $\begin{array}{l}\text { 8. Increment on housing price / High Housing } \\
\text { price }\end{array}$ & & & $\mathrm{x}$ & & $\mathrm{x}$ & & $\mathrm{x}$ & & $\mathrm{x}$ & & & & & $\mathrm{x}$ & 5 \\
\hline $\begin{array}{l}\text { 9. } \begin{array}{l}\text { Housing scheme policy that not intended to } \\
\text { them }\end{array} \\
\text {. }\end{array}$ & & & & & & & & & $\mathrm{x}$ & $\mathrm{x}$ & & & & & 2 \\
\hline $\begin{array}{ll}10 . & \text { Inefficient Housing Allocation / Distribution } \\
\text { System }\end{array}$ & & & $\mathrm{x}$ & & & & & & & & & $\mathrm{x}$ & & & 2 \\
\hline 11. Lack of houses within affordable price & & & $\mathrm{x}$ & & & $\mathrm{x}$ & & & & & $\mathrm{x}$ & & & & 3 \\
\hline $\begin{array}{l}\text { 12. Engaged with other financing commitment } \\
\text { (Too much existing debt) }\end{array}$ & & & & & & $\mathrm{x}$ & & & & & $\mathrm{x}$ & & & & 2 \\
\hline 13. Insufficient income for monthly payments & & & & & & $\mathrm{x}$ & & & & & $\mathrm{x}$ & & & & 2 \\
\hline 14. Insufficient credit score / credit history & & & & & & & & & & & $\mathrm{x}$ & & & & 1 \\
\hline 15. Cheaper to rent than to purchase & & & & & & & & & & & $\mathrm{x}$ & & & & 1 \\
\hline 16. Long waiting list for the houses & $\mathrm{x}$ & & & & & & & & & & & & & & 1 \\
\hline
\end{tabular}

Table 5: Private Developer' Impediment Factors to Affordable Housing Supply

\begin{tabular}{|c|c|c|c|c|c|c|c|c|c|c|c|c|c|c|c|}
\hline 总 & 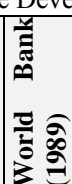 & 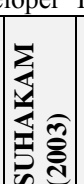 & ڤิ & 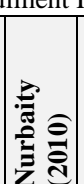 & 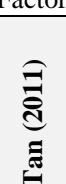 & 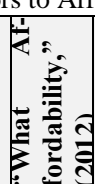 & 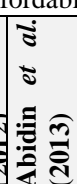 & $\sum_{0}^{3}$ & 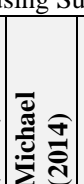 & 尔 & 章 & 幽 & 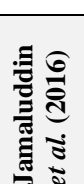 & 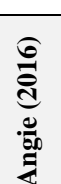 & हَّ \\
\hline $\begin{array}{l}\text { 17. Inconsistency definition of affordable hous- } \\
\text { ing }\end{array}$ & & & & & & & $\mathrm{x}$ & & & & & & $\mathrm{x}$ & & 2 \\
\hline 18. Involvement multiple agencies / stakeholders & & & & & & & $\mathrm{x}$ & $\mathrm{x}$ & & & $\mathrm{x}$ & & $\mathrm{x}$ & $\mathrm{x}$ & 5 \\
\hline $\begin{array}{l}\text { 19. Ineffectiveness affordable housing deliv- } \\
\text { ery/distribution system }\end{array}$ & $\mathrm{x}$ & $\mathrm{x}$ & & $\mathrm{x}$ & & $\mathrm{x}$ & $\mathrm{x}$ & $\mathrm{x}$ & & & $\mathrm{x}$ & & $\mathrm{x}$ & $\mathrm{x}$ & 9 \\
\hline 20. $\quad$ High land cost/price & & $\mathrm{x}$ & $\mathrm{x}$ & & & $\mathrm{x}$ & $\mathrm{x}$ & & & & & & & & 4 \\
\hline 21. Land scarcity & & & $\mathrm{x}$ & $\mathrm{x}$ & & $\mathrm{x}$ & $\mathrm{x}$ & & & & & & & $\mathrm{x}$ & 5 \\
\hline 22. High compliance cost & & & & & & $\mathrm{x}$ & $\mathrm{x}$ & & $\mathrm{x}$ & & $\mathrm{x}$ & & & $\mathrm{x}$ & 5 \\
\hline 23. High construction cost & & $\mathrm{x}$ & $\mathrm{x}$ & & & $\mathrm{x}$ & & & $\mathrm{x}$ & $\mathrm{x}$ & & & & & 4 \\
\hline 24. Highly regulated laws and regulation & $\mathrm{x}$ & $\mathrm{x}$ & $\mathrm{x}$ & & & $\mathrm{x}$ & & $\mathrm{x}$ & & & $\mathrm{x}$ & & & & 6 \\
\hline 25. Inconsistence policies & & & $\mathrm{x}$ & & $\mathrm{x}$ & $\mathrm{x}$ & $\mathrm{x}$ & $\mathrm{x}$ & & & $\mathrm{x}$ & & & & 6 \\
\hline 26. Many uncertainties/unclear guidelines & & & $\mathrm{x}$ & & & $\mathrm{x}$ & & $\mathrm{x}$ & & & $\mathrm{x}$ & & & & 3 \\
\hline 27. $\quad$ Restrictive planning/regulation & & & & & & $\mathrm{x}$ & $\mathrm{x}$ & & & & & & & & 2 \\
\hline 28. Financing stringent & & $\mathrm{x}$ & & & & $\mathrm{x}$ & & & & & $\mathrm{x}$ & & & & 3 \\
\hline 29. Increase business cost & & & $\mathrm{x}$ & & & & & & $\mathrm{x}$ & & & & & & 2 \\
\hline 30. $\quad$ High financing cost & & & & $\mathrm{x}$ & $\mathrm{x}$ & & & & $\mathrm{x}$ & & & & & & 3 \\
\hline 31. Low profit margin / ROI & $\mathrm{x}$ & & $\mathrm{x}$ & & $\mathrm{x}$ & & & & $\mathrm{x}$ & $\mathrm{x}$ & & & & & 5 \\
\hline 32. High infrastructure cost & & $\mathrm{x}$ & & & & & & & & & & & & & 1 \\
\hline 33. Inefficient transportation & & $\mathrm{x}$ & $\mathrm{x}$ & & & & & & & & & & & & 1 \\
\hline 34. Culture of 'facilitating fees' & & $\mathrm{x}$ & & & & & & & & & & & & & 1 \\
\hline 35. Bumiputra quotas \& discounts & & $\mathrm{x}$ & & & & & & & & & $\mathrm{x}$ & & & & 2 \\
\hline $\begin{array}{l}\text { 36. Control on prices and design standards (low- } \\
\text { cost, low-medium) }\end{array}$ & $\mathrm{x}$ & $\mathrm{x}$ & & & & & & & & & & & & & 2 \\
\hline 37. Provision for public amenities & & $\mathrm{x}$ & & & & & & & & & & & & & 1 \\
\hline
\end{tabular}

Table 5: (continued)

\begin{tabular}{|c|c|c|c|c|c|c|c|c|c|c|c|c|c|c|c|}
\hline 总 & 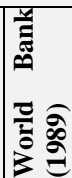 & 帘 & 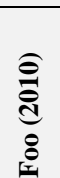 & 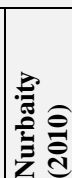 & 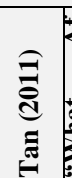 & 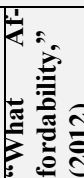 & 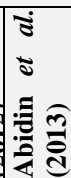 & $\sum_{0}$ & 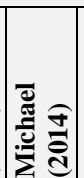 & 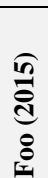 & 章 & 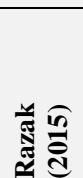 & 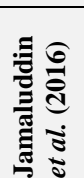 & 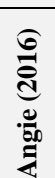 & हूँّ \\
\hline $\begin{array}{l}\text { 38. Varies of legislation, guidelines, rules \& } \\
\text { regulation from state to state, local councils, } \\
\text { governmental and quasi-governmental agen- } \\
\text { cies }\end{array}$ & & $\mathrm{x}$ & & & & & & $\mathrm{x}$ & & & $\mathrm{x}$ & & & & 3 \\
\hline 39. Labour shortage / short-handed skilled labour & & $\mathrm{x}$ & & & & & & & & & & & & & 1 \\
\hline Loose supervision to oversee construction & & $\mathrm{x}$ & & & & & & & & & & & & & 1 \\
\hline
\end{tabular}




\begin{tabular}{|c|c|c|c|c|c|c|c|c|c|c|c|}
\hline & work & & & & & & & & & & \\
\hline 41. & Non-adherence to professionalism & & $\mathrm{x}$ & & & & & & & & 1 \\
\hline 42. & $\begin{array}{l}\text { Lengthy time in processing \& approval appli- } \\
\text { cation }\end{array}$ & $\mathrm{x}$ & & $\mathrm{x}$ & & $\mathrm{x}$ & & & $\mathrm{x}$ & & 3 \\
\hline 44. & $\begin{array}{l}\text { Lack of awareness on what' housing needs } \\
\text { by target group }\end{array}$ & & & & & $\mathrm{x}$ & & & & & 1 \\
\hline 45. & Bureaucracy in the development approval & $\mathrm{x}$ & & $\mathrm{x}$ & $\mathrm{x}$ & & & & & & 2 \\
\hline 46. & Low cost housing policy quota & & & & & & $\mathrm{x}$ & & $\mathrm{x}$ & & 2 \\
\hline 47. & Inefficiency of One-Stop-Centre & & & & & & & & $\mathrm{x}$ & & 1 \\
\hline 48. & Non-uniform transportation network & & & & & & & & $\mathrm{x}$ & & 1 \\
\hline 49. & Lack of bridge financing & & & & & & & & & $\mathrm{x}$ & 1 \\
\hline 50. & BTS policy & & & & & & & & & $\mathrm{x}$ & 1 \\
\hline 51. & Competitive with government entities & & & & & & & $\mathrm{x}$ & & $\mathrm{X}$ & 2 \\
\hline 52. & Developer's Interest bearing scheme (DIBS) & $\mathrm{x}$ & & & & & & & & & 1 \\
\hline & $\begin{array}{l}\text { Obtain permission before making bulk sales } \\
\text { (> } 4 \text { units) }\end{array}$ & $\mathrm{x}$ & & & & & & & & & 1 \\
\hline
\end{tabular}

Table 6: Public Developer' Impediment Factors to Affordable Housing Supply

\begin{tabular}{|c|c|c|c|c|c|c|c|c|c|c|c|c|}
\hline 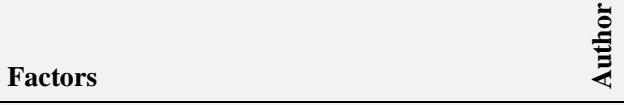 & 氞 & 옹 & 응 & 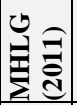 & 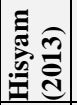 & ฮ를 & 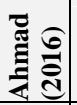 & 曾 & 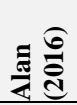 & 总 & 丞 & है \\
\hline 54. Frequent changes in project scope & & & & \begin{tabular}{|l|l}
$\mathrm{x}$ \\
\end{tabular} & & & & & & & & 1 \\
\hline 55. Frequent change in project location / site & & & & $\mathrm{x}$ & & & & & & & & 1 \\
\hline 56. High development standards & & & & $\mathrm{x}$ & & & & & & & & 1 \\
\hline 57. Delays in the issue of loans & & & & $\mathrm{x}$ & & & & & & & & 1 \\
\hline Rep. High land prices/cost & & & & $\mathrm{x}$ & & & $\mathrm{X}$ & & & & & 2 \\
\hline Rep. High prices of infrastructure provisions & & & $\mathrm{x}$ & $\mathrm{x}$ & & & & & & & & 2 \\
\hline $\begin{array}{l}\text { 58. Difficult face in the retrieval of instalments from } \\
\text { buyers }\end{array}$ & & & & $\mathrm{x}$ & & & & & & & & 1 \\
\hline Rep. Scarcity of Land & & & & & & & & $\mathrm{x}$ & & & & 1 \\
\hline 59. Problems in identifying suitable project site & $\mathrm{x}$ & $\mathrm{x}$ & $\mathrm{x}$ & & & & & & & & & 3 \\
\hline 60. Problems in preparation of tender documents & $\mathrm{x}$ & & & & & & & & & & & 1 \\
\hline Rep. High Construction Cost & & & $\mathrm{x}$ & & $\mathrm{x}$ & & & & & & & 2 \\
\hline 61. Absent of solely agencies & & & & & & $\mathrm{X}$ & & & & & & 1 \\
\hline 64. Failed to create public awareness & & & & & & $\mathrm{x}$ & & & & & & 1 \\
\hline 65. Reliance on traditional construction methods & & & & & & & & & & $\mathrm{X}$ & & 1 \\
\hline
\end{tabular}

It was noticed that some of the factors identified in the 1980 s remained in 2016, such as highly regulated laws and regulation, ineffective affordable housing delivery system and high construction cost. As such, it is believed that these factors will continue to persist as problems in the forthcoming years if no plausible solution is introduced. Though most of these factors have been considered and taken into account by the Malaysian government (Minister of Urban Wellbeing, Housing and Local Government (MHLG), 2011; MHLG, 2012; EPU, 2017a), local institutions (BNM, 2016a; KRI, 2015; REHDA 2017) and previous researchers (Nuruddin et al., 2015; Jamaluddin et al., 2016; Fazilah et al., 2016) had searched for measures to address the housing crisis. Yet, the housing crisis in fact still exists the same as in the past. Therefore, a conclusive question needs to be piqued: what is undermining the housing affordability crunch? The main problem can be based off two reasons: first, these factors had been considered as isolated factors by most researchers, rather than as whole; second, these factors are only the surface problem leading to the housing crisis, rather than it's most central problem. And those two reasons lead to fragmented perspectives. Drawing upon such issues, BNM thus called for commitment between the government and private sector in order to meet the affordable housing demand (Cheah and Stefanie, 2017). Yet, critical observations on these factors suggests that, the problems which actually contribute to that factors is far more than mere commitment, but much more on the "soft governance" mechanisms factors: coordination, cooperation and collaboration (3Cs) within the housing players. In tandem with the fact that the housing industry today now involves an ever increasing number of heterogeneous stakeholders, this suggests that a critical approach is needed to include $3 \mathrm{Cs}$ in consolidating these groups of housing stakeholders into a collective-action for the affordable housing solution. With previously fragmented parties becoming more involved and connected, the affordable housing solution would be highly supportive of the entire process of implementation. Such being the case, a plausible solution for the affordable housing crisis lies within the housing governance.

\section{Concluding Remark}

This paper reported a study that identified and categorised the factors leading to the ongoing Malaysian affordable housing crisis. Each of the factors produced its own impact onto the affordable housing shortage, while a combination of all involved factors compounded into the housing gap widening. To avoid the housing crisis from becoming more severe, it is important to consider what actually drives those factors. To this end, this paper identified the lack of cooperation, coordination and collaboration (3Cs) as the main problem behind the factors leading to the Malaysian housing crisis. Given an ever increasing housing actor, it seems likely that a combination of government and non-government advocative approaches are necessary to break the current stalemate of housing dilemma. Thereby, the proposed 'housing governance' is a suitable approach, which brings together various housing stakeholders and match them into a body of collective decision making and action taking. 


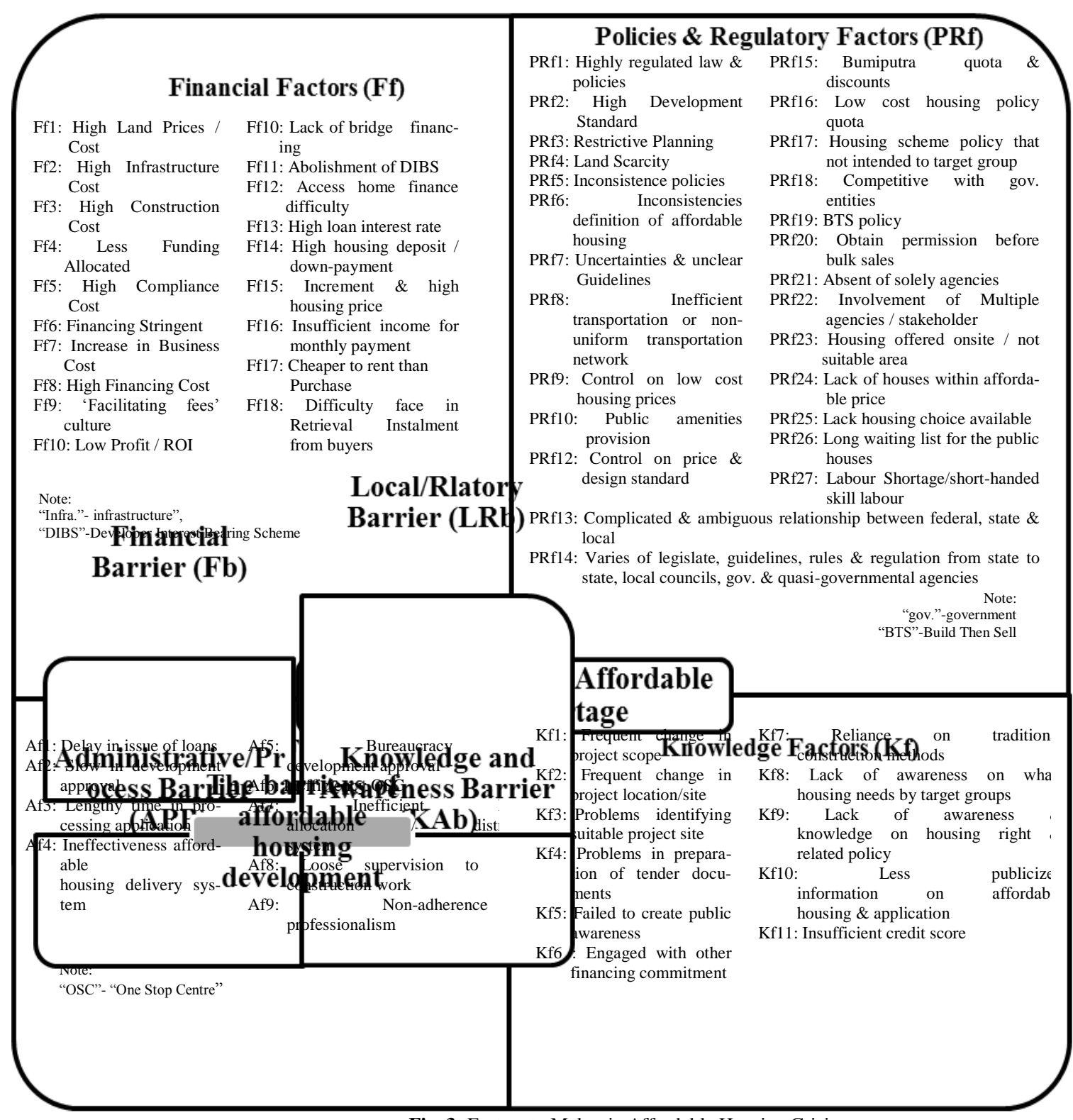

Fig. 3: Factors to Malaysia Affordable Housing Crisis

However, it should be noted that, the main concern of this study lies in the attempt to stimulate the development of housing governance for the Malaysian housing market. Therefore, it should be viewed as a starting point for explaining why 'housing governance' is needed. Instead, researchers will shift their focus to other aspects of research such as by analysing governance determinants and success criteria of housing delivery.

\section{Acknowledgement}

This research work is supported by FRGS under the Grant No. FGRS/1/2015/TK06/UTAR/02/2. The financial contribution is highly appreciated.

\section{References}

[1]. Abidin, M. Z., Wong, S., Teoh, S., \& Ramnath, T. K. (2013). ISIS Roundtable Providing Public and Affordable Housing for Malaysia. Malaysia.

[2]. Ahmad, A. B., \& Hasmah, A. Z. (2008). Evaluation on the Bumiputera Lot Quota Rules On The Bumiputera Housing Ownership In The District Of Johor Bahru, Johor, Malaysia. In A. \& R. Sha- habudin (Ed.), Sustaining Housing Market (First, p. 3). Malaysia: Universiti Teknologi Malaysia.

[3]. Ahmad, N. I., \& Neily, S. E. (2016, November 1). Housing ministry working to standardise land costs, low-cost quotas between states. The Edge Property Malaysia.

[4]. Alan, Tong. (2016, December 10). Solving affordable housing issue. The Star Online. Malaysia.

[5]. Angie, Ng. (2016, April 22). Housing Malaysians with affordable projects. StarProperty.my. Malaysia.

[6]. Bank Negara Malaysia. (2016a). Assessing Demand-Supply Conditions in the Malaysian Property Market. In Annual Report 2015 (pp. $33-45)$.

[7]. Bank Negara Malaysia. (2016b). Financial Stability Report 2015. Bank Negara Malaysia. Retrieved from www.bnm.gov.my

[8]. Bank Negara Malaysia. (2017). Financial Stability and Payment Systems Report 2016.

[9]. Baqutaya, S., Ariffin, a. S., \& Raji, F. (2016). Affordable Housing Policy: Issues and Challenges among Middle-Income Groups. International Journal of Social Science and Humanity, 6(6), 433-436.

[10]. Beer, A. (2012). Housing governance. In International Encyclopedia of Housing and Home (Vol. 3, pp. 497-501). United Kingdom: Elsevier Ltd.

[11]. Bujang, A. A., Jiram, W. R. A., Zarin, H. A., \& Anuar, F. H. M. (2015). Measuring the Gen Y Housing Affordability Problem. International Journal of Trade, Economics and Finance, 6(1), 22-26. 
[12]. Cagamas. (2013). Housing the Nation: Policies, Issues and Prospects. Cagamas Holdings Berhad. Malaysia: Cagamas Holdings Berhad.

[13]. Central Intelligent Agency. (2016). East \& Southeast Asia :: Malaysia. Retrieved from https://www.cia.gov/library/publications/theworld-factbook/geos/my.html

[14]. Cheah, S. ling, \& Stefanie, J. A. (2017). Demystifying the Affordable Housing Issue in Malaysia. In Annual Report 2016 (pp. 91-98) Malaysia: Bank Negara Malaysia.

[15]. CIDB. (2016). CIDB Annual Report 2015. Retrieved from http://www.cidb.gov.my/cidbv5/images/content/2017/korporat/CID B Annual Report 2015.pdf

[16]. CIDB. (2017). Chapter 4 Construction Industry Prospects 2017. In CONSTRUCTION INDUSTRY REVIEW AND PROSPECT 2015/2016.

[17]. Demographia. (2017). 13th Annual Demographia International Housing Affordability Survey: 2017 - Rating Middle-Income Housing Affordability. New Zealand.

[18]. DoS. (2011). Population Distribution and Basic Demographic Characteristics. Dept of Statistics, Malaysia. Retrieved April 1, 2017, from http://doi.org/10.1094/ASBCMOA-StatisticalApp-1

[19]. DoS. (2014). Characteristics of Household 2010 (Updated: 29/1/2014). Dept of Statistics, Malaysia. Retrieved April 1, 2017, from

https://www.statistics.gov.my/images/stories/files/LatestReleases/po pulation/Web_Release_Ciri_IR2010.pdf

[20]. DoS. (2015a). Press Release Report of Household Income and Basic Amenities Survey 2014. Retrieved July 18, 2016, from https://www.statistics.gov.my/dosm/index.php? $r=$ column/cthemeBy Cat\&cat $=120 \&$ bul id $=$ aHhtTHVWNVYzTFBua2dSUlBRL1Rjdz09 \&menu id=amVoWU54UTlOa21NWmdhMjFMMWcyZzO9

[21]. DoS. (2015b). Table 9.7.2: Percentage distribution of household by income class, 2002 - 2014, Malaysia. Retrieved from http://www.epu.gov.my/en/content/table-1-percentage-distributionhouseholds-income-class-malaysia-1970-2014

[22]. DoS. (2016). Population Projection (Revised), Malaysia, 2010-2040. Dept of Statistics, Malaysia. Retrieved April 20, 2017, from http://www.imf.org/external/research/housing/data/HousePricesAr oundtheWorld.csv

[23]. EPU. (1985). Bab XXI - Perumahan.pdf. In Fifth Malaysia Plan, 1986 -1990 (p. 522). Economic Planning Unit. Retrieved from http://www.epu.gov.my/en/rmk/fifth-malaysia-plan-1986-1990

[24]. EPU. (1989). Chapter 14 - Social Development.pdf. In Sixth Malaysia Plan, 1990 - 1995. Malaysia. Retrieved from http://www.epu.gov.my/en/rmk/sixth-malaysia-plan-1990-1995

[25]. EPU. (1995). Chapter 18 - Housing And Other Social Services. In Seventh Malaysia Plan, 1996 - 2000 (pp. 556-557). Retrieved from http://www.epu.gov.my/en/rmk/seventh-malaysia-plan-1996-2000

[26]. EPU. (2010). Ensuring Access to Quality and Affordable Housing. In The Economic Planning (p. 277). Malaysia: The Economic Planning Unit Prime.

[27]. EPU. (2015). Eleventh Malaysia Plan 2016-2020. Malaysia: The Economic Planning Unit Prime.

[28]. EPU. (2016). Economic Performance and Prospects. In Economic Report 2015/16 (pp. 3-11). Malaysia

[29]. EPU. (2017a). 2016 Chapter 1 Economic Management and Prospects. Malaysia.

[30]. EPU. (2017b). 2016/17 Public Sector Finance. Malaysia. Retrieved from www.treasury.gov.my/pdf/economy/er/1617/chapter4.pdf

[31]. Euromonitor. (2017). Malaysia Country Factfile. Retrieved March 20, 2017, from http://www.euromonitor.com/malaysia/countryfactfile

[32]. Fadli, M. (2017, February 23). Skim pembiayaan baru PR1MA tak selesai masalah rakyat, kata Amanah. Freemalaysiatoday.com.

[33]. Fazilah, R., Rozlin, Z., \& Maimunah, A. (2016). Equilibrium price modelling of an affordable housing in Malaysia. International Journal of Supply Chain Management, 5(3), 126-132.

[34]. Foo, L. H. R. (2010). The Institutional Structure of Residential Development Industry in Malaysia. The University of Manchester.

[35]. Foo, Y. N. (2015, November 21). Will slowdown make houses more affordable? TheEdgeProperty.com. Malaysia. Retrieved from http://www.theedgeproperty.com.my/content/will?slowdown?make? houses?more? affordable

[36]. Hisyam, K. (2013, September 3). "We can”t afford to build affordable housing '. Kinibiz. Malaysia.

[37]. Ida, Lim. (2015, February 21). PR1MA initiative a "total failure", consultant claims. Malaymail Online. Malaysia.
[38]. IMF. (2017). House Prices Around the World. Retrieved May 4, 2017 , from http://www.imf.org/external/research/housing/data/HousePricesAr oundtheWorld.csv

[39]. iProperty.com. (2016). ASIA PROPERTY MARKET SENTIMENT REPORT (H2). Malaysia.

[40]. Jamaluddin, N. B., Abdullah, Y. A., \& Hamdan, H. (2016). Encapsulating the delivery of affordable housing : An overview of Malaysian practice. MATEC Web of Conferences, 66(47), 1-8.

[41]. JMA. (2017). Japan Consumer Price Index. Retrieved April 14, 2017, https://www.japanmacroadvisors.com/page/category/economicindicators/inflation-and-prices/cpi/

[42]. Khan, R. A., Liew, M. S., \& Ghazali, Z. Bin. (2014). Malaysian Construction Sector and Malaysia Vision 2020: Developed Nation Status. In 2nd World Conference On Business, Economics And Management - WCBEM 2013 (Vol. 109, pp. 507-513). Malaysia: Elsevier B.V. http://doi.org/10.1016/j.sbspro.2013.12.498

[43]. Khazanah Research Institute. (2015). Making Housing Affordable. Retrieved from http://www.krinstitute.org/form_getfiledownload.aspx? $i d=b 96679 d$ 6-20e8-4597-b9d6-8ae0549f9d6c \& type $=2$

[44]. Khazanah Research Institute II. (2016). The State of Households. Khazanah Research Institute. Kuala Lumpur, Malaysia.

[45]. MHLG. (2011). Arikel 3: Housing in the New Millennium ? Malaysian Perspective. Retrieved February 11, 2017, from http://ehome.kpkt.gov.my/index.php/pages/view/297

[46]. MHLG. (2012). Artikel 4: TOWARDS SUCCESSFUL HOUSING DEVELOPMENT IN MALAYSIA. Retrieved February 11, 2017, from http://ehome.kpkt.gov.my/index.php/pages/view/229

[47]. MHLG. (2016). KPKT Selected Statistics Until 30 SEPTEMBER 2016. Malaysia: Ministry of Urban and Local Wellbeing.

[48]. Michael, K. Y. (2014). The housing delivery system in Malaysia Opportunities \& challenges. In International Union for Housing Finance.

[49]. Milken Institute. (2014). Toward Affordable Housing in Israel. Israel.

[50]. Murphy, P. (2000). Urban governance for more sustainable cities European Environment: The Journal of European Environmental Policy (Wiley), 10(5), 239-246.

[51]. nakono. (2017). Households: Average Household Size (68 countries). Retrieved March 21, 2017, from https://www.nakono.com/tekcarta/databank/households-averagehousehold-sizel

[52]. NAPIC. (2016a). Summary of Existing Stock for Residential, Commercial, Leisure and Industrial property Sub-sector as at Q1Q4 2015. Malaysia: National Property Information Center.

[53]. NAPIC. (2016b). Press Release: Malaysia Property Market 2015. Malaysia: National Property Information Center.

[54]. NAPIC. (2016c). Volume and Value of Property Transaction by Sub-sector year 2001 - 2015. Malaysia: National Property Information Center. Retrieved March 20, 2017, from http://napic.jpph.gov.my/portal

[55]. NAPIC. (2017a). Residential Property Stock Table Q4 2016. Malaysia: National Property Information Center.

[56]. NAPIC. (2017b). The Malaysian House Price Index. Malaysia: National Property Information Center.

[57]. NAPIC. (2017c). Newly Launched Residential Units And The Sales Performances (Q1 2016 , Q2 2016, Q3 2016 And Q4 2016) By State, District, Type And Price Range In Malaysia As At Q4 2016. Malaysia: National Property Information Center.

[58]. NAPIC. (2017d). Property Sales Data - Q3, 2016 Malaysia Q3 2016. Malaysia: National Property Information Center.

[59]. The Malaysian House Price Index. Malaysia: National Property Information Center.

[60]. Nurbaity, A. M., \& Amilia, H. (2010). Housing Policy for the poor in Malaysia and Indonesia.

[61]. Nuruddin, A. R., Abu Bakar, S. P. S., \& Jaafar, M. (2015). Unveiling the challenges faced by Malaysian housing developers through government policy changes. Journal of Construction in Developing Countries, 20(2), 37-52.

[62]. Olanrewaju, A., Rashid, A., Aziz, A., Tan, S. Y., Tat, L. L., \& Mine N. (2016). Market analysis of housing shortages in Malaysia. In Creative Construction Conference 2016 (pp. 317-322).

[63]. Paramesran, R. (2013). The Role of the Banking System. In HOUSING THE NATION: Policies, Issues and Prospects (pp. 137-128). Malaysia: Cagamas Holdings Berhad. 
[64]. Rahimy, R. (2016, October 24). Experts laud affordable home policies. The Star Online. Malaysia.

[65]. Razak, D. A., Mohammed, M. O., \& Tarique, K. M. (2015). Abandoned Housing Projects in Malaysia and the Prospect of DP: An Overview. Procedia Economics and Finance, 31(15), 813-822.

[66]. REHDA. (2016, August). Scenario of Malaysian Housing Loan. REHDA Bulletin Feature Article.

[67]. REHDA. (2017, August). REHDA Budget Wishlist 2017. REHDA Bulletin Feature Article, 4-6.

[68]. SUHAKAM (Human Right Commission of Malaysia). (2013). 2012 Annual Report. Malaysia.

[69]. Saleh, M. (2016, September 16). Affordable housing vis -a- vis moneylending what say you ... Malaysiakini. Malaysia.

[70]. Syed, J. Z. (2016, October 18). How a Skewed System keeps house prices high and developers rich. Malaymail Online. Malaysia

[71]. Syed, N. (2016, February 23). Bizarre issue of fresh grad salaries. New Straits Times.

[72]. Tan, W. K. (2013). Meeting the Needs of Homeownership. In HOUSING THE NATION: Policies, Issues and Prospects (p. 9). Malaysia: Cagamas Holdings Berhad.

[73]. UN-Habitat. (2011). Affordable Land and Housing in Asia.

[74]. G.Vinod. (2013, February 20). A 10-year wait and still no homes. Free Malaysia Today.

[75]. What Affordability Means To Developers. (August 24, 2012). New Straits Times. Malaysia.

[76]. Woetzel, J., Ram, S., Mischke, J., Garemo, N., \& Sankhe, S. (2014). A blueprint for addressing the global affordable housing challenge. McKinsey Global Institute, (October), 212.

[77]. World Bank. (1989). Malaysia the Housing Sector Getting the Incentives Right.

[78]. Zunaira, S. (2016, December 22). PR1MA sets realistic targets. The Star Online. Malaysia. 